DOI https://doi.org/10.32847//n.2021.13.2.10

\title{
Пилипів B.I.
} здобувач кафедри адміністративного та господарського права Запорізький нащіональний університет

\section{ПРАВО НА СЛУЖБУ В ОРГАНАХ МІСЦЕВОГО САМОВРЯДУВАННЯ: ОСНОВИ РЕГЛАМЕНТАЦЇ̈}

Постановка проблеми. У контексті дослідження адміністративно-правового регулювання службових правовідносин в органах місцевого самоврядування важливо також взяти до уваги тези, які узагальнила Л.Р. Біла-Тіунова, досліджуючи публічну службу як адміністративно-правову категорію. Відома фахівець 3 адміністративного права запропонувала уважати, що «особливістю законодавства про публічну службу є те, що:

a) відсутній єдиний законодавчий акт, який передбачав би основоположні засади публічної служби (поняття, особливості, види, принципи публічної служби, поняття та види публічних службовців, способи вступу на публічну службу, основи проходження публічної служби, атестація публічних службовців, основні підстави припинення публічної служби, відповідальність публічних службовців);

б) чинне законодавство $є$ некодифікованим, несистемним, розрізненим і таким, в якому переважають підзаконні нормативні акти» [1, c. 143].

Аналіз останніх досліджень і публікацій. Проблеми, окреслені у статті, досліджувала низка вчених - фахівців з адміністративного права. При написанні статті було використано напрацювання таких дослідників, як Біла-Тіунова Л.Р., Аніщенко Т.С., Колпаков В.К., Бедний О.В., Лазор О.Д., Лазор О.Я. та інших фахівців $з$ юридичних наук (переважно 3 конституційного права України - Н.В. Мішиної, І.Б. Коліушко, В.П. Тимощук, інших).

Мета статті. Метою статті $є$ аналіз того, як право на службу в органах місцевого са- моврядування регламентується у сучасному законодавстві України.

Виклад основного матеріалу. Т.С. Аніщенко запропонувала вести мову про «право публічної служби» в системі адміністративного права, розглядаючи його як «підгалузь особливої частини адміністративного права» [2, с. 5]. Над питаннями «службового права» неодноразово розмірковували і інші автори (дивись, наприклад, [3; 4; 5]).

Відомий вчений - фахівець 3 адміністративного права В.К. Колпаков сформулював, що серед понять «службове право», «право публічної служби», «публічно-службове право», «публічне службове право» слід надати перевагу використанню терміна «службове право» [6, с. 120-121], погоджуючись, таким чином, з професором Т.О. Коломоєць. Слід відмітити ще низку праць фахівців 3 адміністративного права запорізької галузевої школи 3 цього питання, а саме монографію «Службове право: витоки, сучасність та перспективи розвитку», що вийшла друком у 2017 році, та навчальний посібник «Заохочення у службовому праві», який було надруковано у тому ж році.

Також варто додати, що публічна служба в Україні у цілому та служба в органах місцевого самоврядування зокрема постійно удосконалюється з урахуванням зарубіжного досвіду та найкращих європейських стандартів.

Публічна влада в Україні на сучасному етапі представлена як державною владою, так і місцевим самоврядуванням.

Таким чином, дослідники справедливо доходять висновку, що публічна служба 


\section{АДМІНІСТРАТИВНЕ ПРАВО І ПРОЦЕС; ФIHАНСОВЕ ПРАВО; ІНФОРМАЦИИНЕ ПРАВО}

представлена двома такими різновидами, як державна служба та служба в органах місцевого самоврядування.

Л. Стельмащук, аналізуючи співвідношення понять "публічна служба" та "державна служба", зауважила, що «державну службу слід розглядати як елемент публічної з урахуванням iii головної мети - стати повсякденним каналом зв’язку держави та народу, їх взаємодії, а також бути лідируючою силою суспільства» [7, с. 9].

Поняття «державна служба» міститься в такому акті чинного законодавства, як Закон України від 10 грудня 2015 року «Про державну службу». Відповідно до цього нормативно-правового акту, «державна служба - це публічна, професійна, політично неупереджена діяльність із практичного виконання завдань і функцій держави, зокрема щодо:

1) аналізу державної політики на загальнодержавному, галузевому i регіональному рівнях та підготовки пропозицій стосовно iii формування, у тому числі розроблення та проведення експертизи проектів програм, концепцій, стратегій, проектів законів та інших нормативно-правових актів, проектів міжнародних договорів;

2) забезпечення реалізації державної політики, виконання загальнодержавних, галузевих і регіональних програм, виконання законів та інших нормативно-правових актів;

3) забезпечення надання доступних і якісних адміністративних послуг;

4) здійснення державного нагляду та контролю за дотриманням законодавства;

5) управління державними фінансовими ресурсами, майном та контролю за їх використанням;

6) управління персоналом державних органів;

7) реалізації інших повноважень державного органу, визначених законодавством» [8].

Варто зазначити, що ця нормативна дефініція поняття «державна служба» на сучасному етапі розвитку української юридичної літератури є самою детальною. Жодна 3 інших дефініцій, сформульованих вченими, не $є$ настільки грунтовною.
Наприклад, такі визначення містяться у виданні «Державна служба в Україні» авторства Лазор О.Д., Лазор О.Я. [9], у науковопрактичному коментарі до Закону України «Про державну службу» [10], у підручниках, присвяченних питанням публічної служби у цілому та державної служби зокрема [11], в інших наукових виданнях монографічного характеру та у статтях у наукових журналах України.

Однак, варто зауважити, що державна служба не є предметом нашого дослідження, а тому ані ці дефініції, ані наші міркування 3 їх приводу наводитися не будуть.

Аналізуючи службу в органах місцевого самоврядування у контексті ऑiі конституційної регламентації, слід взяти до уваги те, що, як влучно сформулював відомий фахівець 3 адміністративного права України Є.В. Додін, адміністративно-правове регулювання будьякої сфери «охоплює цілісну сукупність нормативно-правових актів, що містять основний масив норм національного права, чи єдність, забезпечену передусім встановленими у Конституції принципами, іншими вихідними положеннями, та складається 3 інститутів, функціонально орієнтованих на досягнення цілей і ідеалів, позначених в ii центральній підсистемі -законодавстві» [12, с. 71].

Отже, відомий фахівець 3 адміністративного права уважав, що саме конституційні вихідні положення у цілому та принципи зокрема мають скеровувати адміністративно-правову регламентацію кожного інституту, підінституту адміністративного права. 3 цієї точки зору слід звернути увагу на окремі положення Розділу II Конституції України.

Назва цього розділу - «Права, свободи та обов'язки людини і громадянина». А отже, у ньому йтиметься здебільшого про тих осіб, які наділені правом на службу в органах місцевого самоврядування.

По-перше, у цьому розділі важливим $\epsilon$ посилання на загальні положення, що стосуються прав людини у цілому. 


\section{АДМІНІСТРАТИВНЕ ПРАВО І ПРОЦЕС; ФIHAHCOBЕ ПРАВО; ІНФОРМАЦІЙНЕ ПРАВО}

Так, речення друге статті 21 передбачає, що «права і свободи людини $\epsilon$ невідчужуваними та непорушними». Це $є$ важливим з точки зору того, що усі суб'єкти права на службу в органах місцевого самоврядування мають гарантії реалізації цього права, які надаються державою та громадянським суспільством. Про це свідчить і частина друга, третя статті 22, відповідно до положень, закріплених у яких:

«Конституційні права і свободи гарантуються і не можуть бути скасовані.

При прийнятті нових законів або внесенні змін до чинних законів не допускається звуження змісту та обсягу існуючих прав і свобод».

По-друге, частина перша статті 22 передбачає, що «права і свободи людини і громадянина, закріплені цією Конституцією, не є вичерпними». А тому, попри те, що право на службу в органах місцевого самоврядування як таке формально не згадується в Основному Законі, це не означає його відсутність у цілому. Адже у статті 38 йдеться про те, що «громадяни користуються рівним правом доступу до державної служби, а також до служби в органах місцевого самоврядування», - а не про право на доступ до служби в органах місцевого самоврядування.

Нарешті, у контексті останнього твердження, важливим $\epsilon$ те, як саме розуміється принцип рівності у цілому, якщо звертатися по його тлумачення до Конституції України 1996 року.

Цьому питанню в Основному Законі 1996 року присвячено статтю 24. Відповідно до іiї положень:

«Громадяни мають рівні конституційні права і свободи та $є$ рівними перед законом.

Не може бути привілеїв чи обмежень за ознаками раси, кольору шкіри, політичних, релігійних та інших переконань, статі, етнічного та соціального походження, майнового стану, місця проживання, за мовними або іншими ознаками.

Рівність прав жінки і чоловіка забезпечується: наданням жінкам рівних 3 чоловіками можливостей у громадсько-політичній і куль- турній діяльності, у здобутті освіти і професійній підготовці, у праці та винагороді за неї; спеціальними заходами щодо охорони праці і здоров'я жінок, встановленням пенсійних пільг; створенням умов, які дають жінкам можливість поєднувати працю 3 материнством; правовим захистом, матеріальною і моральною підтримкою материнства i дитинства, включаючи надання оплачуваних відпусток та інших пільг вагітним жінкам і матерям».

Слід зауважити, що в Конституції України 1996 року принцип рівності знайшов своє відображення в відповідності до найновіших стандартів прав людини міжнародного та європейського рівня.

Варто зазначити, що конституційний принцип рівності часто справедливо іменують «принципом юридичної рівності» або «принципом правової рівності». Цей принцип $\epsilon$ таким, який охоплює рівність перед законом (у широкому розумінні цього поняття) та рівність перед судом. А тому цілком зрозуміло, чого його часто іменують так, як зазначено на початку цього абзацу.

Принцип рівності $є$ важливим, коли йдеться про будь-яке право людини, і право на службу в органах місцевого самоврядування не є виключенням. А те, що в Конституції України 1996 року йдеться про «рівне право доступу до служби в органах місцевого самоврядування», акцентує увагу на необхідності розуміння його сучасної сутності.

Людиноцентристський напрям сучасного розвитку адміністративного права України привертає увагу до того, що особистості для вільного розвитку необхідно мати не тільки правовільний простір (громадянське суспільство), але й належний рівень рівності у взаємодії з органами публічної влади. У контексті досліджуваного питання це означає два основних напрями:

по-перше, можливість спілкуватися (звертатися, отримувати відповіді, допомогу тощо) 3 органами місцевого самоврядування, 3 виборними особами та зі службовцями цих органів, при цьому ставлення до кожної особи з боку згаданих суб'єктів має бути однаковим; 


\section{АДМІНІСТРАТИВНЕ ПРАВО І ПРОЦЕС; ФIНАНСОВЕ ПРАВО; ІНФОРМАЦИИНЕ ПРАВО}

по-друге, за наявності бажання, особа повинна мати рівні з іншими можливості бути обраною чи поступити на службу до органів місцевого самоврядування.

В кожному з цих двох випадків принцип рівності $\epsilon$ надзвичайно важливим. Важко сказати, у першому чи у другому випадку він матиме пріоритетне значення зокрема.

Традиційним для органів публічної влади $\epsilon$ те, що вони не вмішуються у функціонування інститутів громадянського суспільства. А тому дослідження адміністративно-правового регулювання служби в органах місцевого самоврядування спрямоване як раз на те, як же якомога більш повно забезпечити практичну реалізацію принципу рівності у контексті служби в органах місцевого самоврядування.

В юридичній літературі поширеною є думка, що принцип рівності полягає у наступному:

«- рівність у правах;

- рівність «у законі» (формально-юридична рівність);

- рівний правових захист» [13, с. 19].

Слід повністю погодитись 3 таким підходом та продовжити стислий аналіз конституційного принципу рівності у тому контексті, який $є$ важливим для адміністративно-правового регулювання службових правовідносин в органах місцевого самоврядування.

Євроінтеграційні прагнення України зумовлюють той факт, що важливим документом, коли йдеться про весь розвиток національного законодавства у цілому та адміністративного законодавства зокрема, є Конвенція про захист прав людини і основоположних свобод 1950 року.

У цій Конвенції принципу рівності у цілому присвячена стаття 14 «Заборона дискримінації». Також не можна оминути увагою Протокол N 12 до Конвенції про захист прав людини і основоположних свобод, точніше преамбулу і першу статтю цього протоколу.

На підставі вищенаведених положень аналізується кожне з прав, що захищається Конвенцією 1950 року, якщо є ймовірність порушення принципу рівності у конкретному випадку.

Варто зауважити, що право на службу в органах місцевого самоврядування Конвенція 1950 року не захищає. Вона сконцентрована навколо особистих прав, 3 певними винятками, а право на службу в органах місцевого самоврядування традиційно належить до прав політичних.

I тим не менш, розуміння принципу рівності Європейським судом 3 прав людини $\epsilon$ надзвичайно важливим у контексті нашого дослідження. А тому, на підставі аналізу практики Європейського суду з прав людини щодо застосування статті 14 (у тому числі це рішення у справі Eweida and others v. United Kingdom (2013), S.A.S. v. France (2015), Konstantin Markin v. Russia (2010), Khamtokhu and Aksenchik v. Russia (2017), Sejdic and Finci v. Bosnia and Herzegovina (2009), Hamidovic v. Bosnia and Herzegovina (2017), Molla Sali v. Greece (2019), Ecis v. Latvia (2019)) було сформульовано висновок до цієї статті (дивись нижче).

Висновки. Для України важливим $є$ те, що Європейський суд 3 прав людини при захисті прав людини виходить 3 того, що принцип рівності наразі гарантує визначеність законодавства (тобто, він тісно пов'язаний з принципом правової визначеності) та означає:

- дотримання вимог до визначеності законодавства, у якому має міститися принцип рівності;

- дотримання вимог до визначеності судових рішень, які мають прийматися 3 дотриманням принципу рівності;

- дотримання вимог до визначеності меж повноважень органів публічної влади, які при їх здійсненні мають дотримуватися принципу рівності.

Також слід запропонувати уточнити тезу, відповідно до якої право на службу в органах місцевого самоврядування іменують «конституційним правом». Слід уважати, що конституційним є право рівного доступу до служби в органах місцевого самоврядування. 


\section{АДМІНІСТРАТИВНЕ ПРАВО І ПРОЦЕС; ФIHAHСОВЕ ПРАВО; ІНФОРМАЦІЙНЕ ПРАВО}

Якщо застосовувати текстуальний підхід до вивчення тексту Конституції України як основного джерела галузі адміністративного права. Право на службу в органах місцевого самоврядування, право бути обраним до органів місцевого самоврядування прямо не передбачені, але витікають 3 аналізу тексту Конституції.

Перспективи подальших досліджень у цьому напрямі полягають в оновленні адміністративно-правових поглядів на право служби в органах місцевого самоврядування.

\section{Анотація}

Публічна влада в Україні на сучасному етапі представлена як державною владою, так і місцевим самоврядуванням.

Таким чином, дослідники справедливо доходять висновку, що публічна служба представлена двома такими різновидами, як державна служба та служба в органах місцевого самоврядування.

Метою статті є аналіз того, як право на службу в органах місцевого самоврядування регламентується у сучасному законодавстві України.

Виявлено, що у Розділі II Конституції України важливим є посилання на загальні положення, що стосуються прав людини у цілому. Так, речення друге статті 21 передбачає, що «права і свободи людини є невідчужуваними та непорушними». Це є важливим з точки зору того, що усі суб'єкти права на службу в органах місцевого самоврядування мають гарантії реалізації цього права, які надаються державою та громадянським суспільством. Про це свідчить і частина друга, третя статті 22.

Свроінтеграційні прагнення України зумовлюють той факт, що важливим документом, коли йдеться про весь розвиток національного законодавства у цілому та адміністративного законодавства зокрема, є Конвенція про захист прав людини і основоположних свобод 1950 року.

Для України важливим є те, що Свропейський суд з прав людини при захисті прав людини виходить 3 того, що принцип рівності наразі гарантує визначеність законодавства (тобто, він тісно пов'язаний з принципом правової визначеності) та означає:

- дотримання вимог до визначеності законодавства, у якому має міститися принцип рівності;

- дотримання вимог до визначеності судових рішень, які мають прийматися з дотриманням принципу рівності;

- дотримання вимог до визначеності меж повноважень органів публічної влади, які при їх здійсненні мають дотримуватися принципу рівності.

Також слід запропонувати уточнити тезу, відповідно до якої право на службу в органах місцевого самоврядування іменують «конституційним правом». Слід уважати, що конституційним є право рівного доступу до служби в органах місцевого самоврядування. Якщо застосовувати текстуальний підхід до вивчення тексту Конституції України як основного джерела галузі адміністративного права. Право на службу в органах місцевого самоврядування, право бути обраним до органів місцевого самоврядування прямо не передбачені, але витікають з аналізу тексту Конституції.

Ключові слова: служба в органах місцевого самоврядування, виборні посадови особи місцевого самоврядування, службовці органів місцевого самоврядування, правовідносини на службі в органах місцевого самоврядування, публічна влада, право на службу в органах місцевого самоврядування. 


\section{АДМІНІСТРАТИВНЕ ПРАВО І ПРОЦЕС; ФІНАНСОВЕ ПРАВО; ІНФОРМАЦІЙНЕ ПРАВО}

\section{Pylypiv V.I. Right to service in local government: fundamentals of regulations}

\section{Summary}

Public power in Ukraine at the present stage is represented by both state power and local selfgovernment.

Thus, researchers rightly conclude that public service is represented by two types, such as public service and service in local governments.

The purpose of the article is to analyze how the right to serve in local governments is regulated in modern legislation of Ukraine.

It was found that in Section II of the Constitution of Ukraine it is important to refer to general provisions concerning human rights in general. Thus, the second sentence of Article 21 states that "human rights and freedoms are inalienable and inviolable." This is important from the point of view that all subjects of the right to serve in local self-government bodies have guarantees of realization of this right, which are provided by the state and civil society. This is evidenced by the second and third parts of Article 22.

Ukraine's European integration aspirations are conditioned by the fact that the Convention for the Protection of Human Rights and Fundamental Freedoms of 1950 is an important document when it comes to the entire development of national legislation in general and administrative legislation in particular.

It is important for Ukraine that the European Court of Human Rights in protecting human rights assumes that the principle of equality currently guarantees the certainty of legislation (ie, it is closely linked to the principle of legal certainty) and means:

- compliance with the requirements for the definition of legislation, which should contain the principle of equality;

- compliance with the requirements for the certainty of court decisions to be made in compliance with the principle of equality;

- compliance with the requirements for defining the limits of the powers of public authorities, which in their implementation must adhere to the principle of equality.

It should also be suggested to clarify the thesis according to which the right to serve in local selfgovernment bodies is called a "constitutional right". It should be considered that the right of equal access to service in local self-government bodies is constitutional. If we apply the textual approach to the study of the text of the Constitution of Ukraine as the main source of administrative law. The right to serve in local self-government bodies, the right to be elected to local self-government bodies are not directly provided, but follow from the analysis of the text of the Constitution.

Key words: service in local self-government bodies, elected officials of local self-government bodies, employees of local self-government bodies, legal relations in the service in local selfgovernment bodies, public authorities, right to serve in local self-government bodies.

\section{Список використаних джерел:}

1. Біла-Тіунова Л.Р. Публічна служба як адміністративно-правова категорія. Наукові пращі Одеської національної юридичної академії. Одеса : Юрид. л-ра, 2009. Т. 8. С. 142-154.

2. Аніщенко Т.С. Право публічної служби у системі адміністративного права України: автореф. дис. .... канд. юрид. наук. Запоріжжя, 2015. 15 с.

3. Мішина Н.В. Участь населення у місцевому самоврядуванні: регламентація в концепціях української муніципальної реформи. Вісник Південного регіонального иентру Національної академії правових наук України. 2019. № 20. С. 48-53.

4. Mishyna N.V. Guarantees of Local Government in Ukraine | Гарантії місцевого самоврядування в Україні. ЮРИДИКА | JURIDICA. 2020. № 2. С. 15-18. 


\section{АДМІНІСТРАТИВНЕ ПРАВО І ПРОЦЕС; \\ ФІНАНСОВЕ ПРАВО; \\ ІНФОРМАЦІЙНЕ ПРАВО}

5. Mishyna N.V. Self-Organized Bodies of the Population and the Local Government's Nature Concepts | Органи самоорганізації населення у контексті теорій про природу місцевого самоврядування. ЮРИДИКА | JURIDICA. 2020. № 1. С. 16-20.

6. Колпаков В.К. Публічна служба в сучасній парадигмі адміністративного права України. Службове право: витоки, сучасність та перспективи розвитку: колективна монографія / за заг. ред. Т.О. Коломоєць, В.К. Колпакова. Запоріжжя: Гельветика, 2017. С. 84-123.

7. Бедний О.В. Організаційно-правові основи служби в органах місцевого самоврядування: дис. ... канд.юрид. наук. Одеса, 2003. 177 с.

8. Про державну службу: Закон України від 10 грудня 2015 року URL: https://zakon.rada.gov. ua/laws/show/889-19

9. Лазор О.Д., Лазор О.Я. Державна служба в Україні. К.: Видавничий Дім «Дакор», 2009. 560 с.

10. Науково-практичний коментар до Закону України «Про державну службу» / Ред. кол.: К.О. Ващенко, І.Б. Коліушко, В.П. Тимощук, В.А.Дерець (відп. ред.). К.: ФОП Москаленко О.М., 2017. 796 с.

11. Ківалов С.В., Біла-Тіунова Л.Р. Публічна служба в Україні: Підручник. Одеса: Фенікс, 2009. $688 \mathrm{c}$.

12. Додин Е. В. Административная ответственность в свете Конституции Украины. Юридичний вісник. 1997. No 3. С.70-74.

13. Тилежинский Е.В. Равенство как правовая категория: дис. ... канд. юрид. наук. Самара, 2006. 230 c. 